\title{
Contamination during Use
}

National Cancer Institute

\section{Source}

National Cancer Institute. Contamination during Use. NCI Thesaurus. Code C63018.

Problem associated with the undesired introduction of impurities either chemical or

microbiological in nature, or of foreign matter into or onto a device at the user facility. 